\title{
Geoelectrical Sounding For Groundwater Interpretation In Oil Palm Plantation
}

\author{
[Z. B. Caniago', R. Ekawita1 ${ }^{1}$, Supanjani², A. D. Nusantara $^{2}$ \& Y.I. Intara $\left.{ }^{3}\right]$
}

\begin{abstract}
Data on aquifer characteristic is an important factor in studying groundwater, especially to determine the capacity of groundwater, which can be stored in the soil layer and how much that can be utilized. Geoelectrical survey was applied to observed groundwater at oil palm plantation. The research was conducted in PT. Bio Nusantara oil palm plantation, Bengkulu Province, Indonesia especially at 2, 4, 7, 14 and 22 years of mature plant age (TM). As a comparison for the mature plant age level, the survey was also performed at the oil palm plantation farm-soccer field, oil palm plantation farm-residential and oil palm plantation farm- secondary forest. The result of electric survey on TM2 and TM4 showed some rocks, clay and dry litter still existed. While at the depth over than $4 \mathrm{~m}$ was dominated by a shallow aquifer. The dry zone wasn't found at site of TM7, TM14 and TM22, all sites was in high soil humidity. The electric survey result at oil palm plantation farm-soccer field indicated that able to maintain the balance of soil-water availability, there is a shallow aquifer zone at the residential site and a water scarcity at secondary forest site.
\end{abstract}

Keywords—geoelectrical, oil palm, groundwater

\section{Introduction}

Ground water is all water found in a layer of soil or rock beneath the subsurface which is can be as a future water resources ( Todd and Mays, 2005; Saleem and El-Sayed, 2015). Groundwater comes from water lies in the soil surface area (rainwater, lake water and so on) then moves in to soil layer in recharge area and then flows to discharge area (Sheriff, 2002; Mays, 2006). Water in the subsurface will join to form a layer called the aquifer.

Dong, et al. (2013) and Suharto (1997) confirmed that the availability of water sources is influenced by climate, morphology, geology and natural vegetation factors in an area. Vegetation in an area will help the process of water absorption into the soil (Wahyudi and Moersidik, 2016). The aquifers in the subsurface are helpful in maintaining soil moisture levels as they affect production levels in the agri-

\section{R. Ekawital, Z. B. Caniago ${ }^{1}$}

Faculty of Mathematics and Natural Sciences, The University of Bengkulu, Jl. WR. Supratman Kandang Limun Bengkulu, 38371 Indonesia,

Supanjani ${ }^{2}$, A. D. Nusantara ${ }^{2}$

Faculty of Agriculture, The University of Bengkulu, Jl. WR. Supratman Kandang Limun Bengkulu, 38371

Indonesia,

Y.I. Intara

Faculty of Agriculture, The Universitas of Mulawarman, Jl. Paser Balengkong Kampus Gunung Kelua Samarinda,

Indonesia culture in both seasonal and annual crops such as oil palm (Subramaniam et al., 2014).

The characteristics of the aquifers are important factor to study a ground water capacity in store and utilize in subsurface of soil. According to the hydrological cycle, the aquifer layer has a dual function as a storage and a conduit medium (Smith et al., 2017).

The studies of the aquifer have been carried out, such as the level of availability for the future as water source (Wahyudi and Moersidik., 2016), pollutants in ground water (Oni et al., 2017), bacterial contamination (Kovacic et al., 2017; Elfadaly et al., 2017), chemical composition (Salem and El -Sayed, 2015) etc. Aquifer investigation can be done by using geoelectric method. This geophysics method is a useful method of subsurface structure and thickness investigation, poluttan infiltration, erosive mechanism (Orlando, 2013; Mohamaden, 2016) etc. Geoelectric methods as non-disturb method of the observed object result an electrical resistivity value at each of soil depth (Mostafa et al., 2017). The resistivity value will be inversely proportional to the groundwater content (Abidin et al., 2017; Bhatt and Jain, 2014). Based on the electrical resistivity value, the aquifers area will be known. So in this paper will be reported results of investigation of groundwater characteristics in oil palm plantations using geoelectric method with the Wenner-Sclumberger configuration.

\section{Material and Method}

This research was conducted in PT. Bio Nusantara, Central Bengkulu Regency of Bengkulu Province, information about geological properties was based on geological map sheet of Bengkulu (0912) Sumatera scale of 1: 250.000 (Puslitbang Geologi, 1992). The geological map shows that the geological characteristic of Central Bengkulu Regency is dominated by sedimentary rocks and volcanoes, breakthrough rocks and surface sediment. According to Semi Detailed Map of Central Bengkulu Regency scale of 1: 50.000 update version (BBSDLP 2016) and field verification indicated that the soil found in Central Bengkulu Regency according to National Soil Classification (SUBARDJA et al 2016) consisted of 8 orders with 15 suborders. The suitability according to Keys to Soil Taxonomy (Soil Survey Staff, 2014) is presented in Table 1.

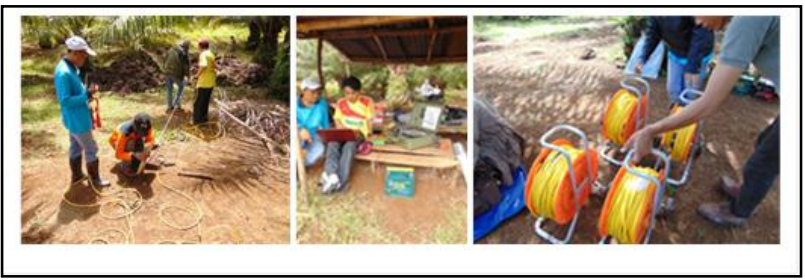

Figure 1. Sounding research for groundwater level measurement using geoelectrical method in PT. Bio Nusantara Bengkulu

Selected oil palm plantation sites were under replanting2 years of mature plant age (TM2), under-replanting-4 years 
mature plant age (TM4), 7 (TM7), 14 (TM14), 22 (TM22) years mature plant age, and oil palm plantation- soccer field border, oil palm plantation-residential border, and oil palm plantation - secondary forest border.

The geoelectrical survey was conducted using a 46 channel Resistivity-Induced Polarization meter X612-EM made by MAE-Italy (Figure 1). This method located electrodes with $4 \mathrm{~m}$ space and $100 \mathrm{~m}$ width. Electrodes were placed parallel $(2 \mathrm{~m}$ ) from rows of oil palm tree, covering 10 oil palm trees. Data processing of the result geoelectrical measurement was done using software ERTLAB dan software view Lab3D.

TABLE 1. SOIL IN CENTRAL BENGKULU REGENCY, BENGKULU

\begin{tabular}{|l|l|l|}
\hline Orders & Suborders & Subgrup \\
\hline Organosol & Organosol Sapric & Typic Haplosaprists \\
\hline \multirow{2}{*}{ Aluvial } & Aluvial Sulfic & Sulfic Endoaquents \\
\cline { 2 - 3 } & Aluvial Gleic & Typic Endoaquents \\
\hline Regosol & Regosol Distric & Typic Udipsamments \\
\hline Latosol & Latosol Gleic & Aquic Dystrudepts \\
\cline { 2 - 3 } & Latosol Oksic & Oxic Dystrudepts \\
\hline \multirow{5}{*}{ Gleiosol } & Cambisol Gleic & Aquic Dystrudepts \\
\cline { 2 - 3 } & Cambisol Litic & Lithic Dystrudepts \\
\cline { 2 - 3 } & Cambisol Distric & $\begin{array}{l}\text { Fluventic Dystrudepts Typic } \\
\text { Dystrudepts }\end{array}$ \\
\cline { 2 - 3 } & Gleisol Sulfiidic & Sulfic Endoaquepts \\
\cline { 2 - 3 } & Gleisol Distric & Typic Endoaquepts \\
\cline { 2 - 3 } Nitosol & Gleisol Eutric & Typic Endoaquepts \\
\hline Podsolic & Nitosol Distric & Typic Paleudults \\
& $\begin{array}{l}\text { Podsolic Kandic } \\
\text { Podsolic Haplic }\end{array}$ & $\begin{array}{l}\text { Typic Kanhapludults } \\
\text { Typic Hapludults }\end{array}$ \\
\hline \multirow{2}{*}{ Source: Semi Detail Map of Central Bengkulu Regency scale of 1: 50.000 } \\
& \multicolumn{2}{|c|}{ update version (BBSDLP 2016). } \\
\hline \multicolumn{2}{|c|}{} & \\
\hline
\end{tabular}

\section{Results and Discussions}

The type of soil found in the study sites was cambisol. Cambisol was the developed soil, indicated by the A-Bw-C horizon layer on well drained soil, and the $\mathrm{A}-\mathrm{Bg}-\mathrm{C}$ horizon layers in the inhibited - drained soil (Table 1). Cambisol soil found at various levels was classified as Cambisol Gleic, Cambisol Litic, and Cambisol District.

The soil texture at the study site as depicted in Table 2 showed high clay content in which clay soil didn't only had a large surface but also contained of electric charge. Electric charge makes clay enable to bind water or plant nutrient on its surface. This causes clay is able to store water more. However, clay is also an impermeable layer if beneath the soil surface.

Each soil surface has a slope that causes groundwater movement. The free groundwater surface has a hydraulic gradient, then water will move toward a direction that has a low gradient. Groundwater movement can be determined by groundwater flow pattern. Groundwater flow is groundwater that moves into the space between the permeable soil. Geoelectrical or vertical electric sounding is conducted to determine the condition of the subsurface based on resistivity value.

Figure 2 shows a sounding result of groundwater height level in the TM2 site of oil palm plantation of PT Bio Nusantara, Bengkulu. Table 3 presents several color zones at 0-1,6 m of surface depth. Red and yellow color were thought due to distribution of rocks, clay and dry litter during replanting while at the deeper side showed blue and purple color indicating high groundwater content especially for purple color which assumed as shallow aquifer.

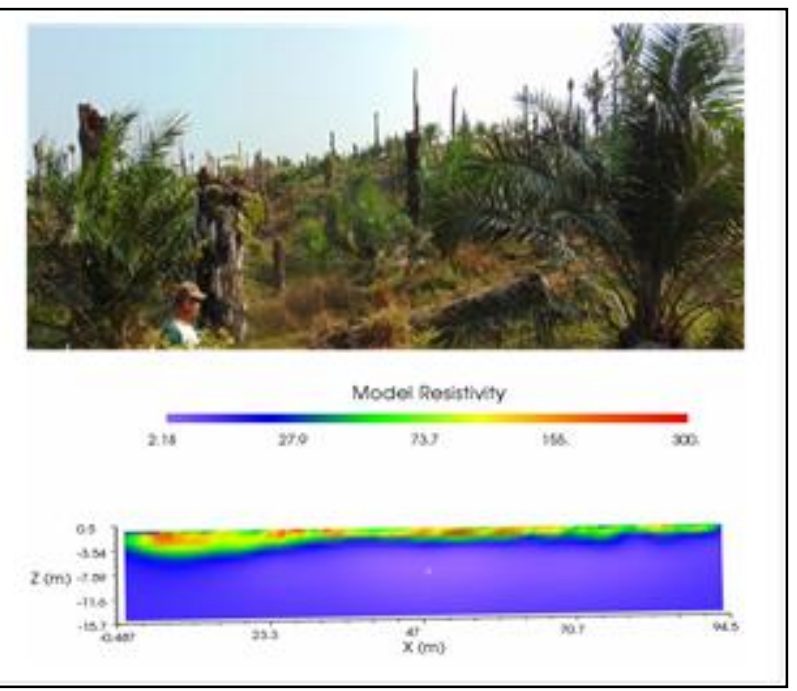

Figure 2. Geoelectrical measurement result of TM2 site

TABLE 3. GEOELECTRICAL RESULT OF TM2 $\left(3^{\circ} 36\right.$ ' 45.84 ”SL AND $\left.102^{\circ} 17 ' 24.08^{\prime \prime} \mathrm{EL}\right)$

\begin{tabular}{|l|l|l|l|}
\hline $\begin{array}{c}\text { Depth } \\
(\mathbf{m})\end{array}$ & $\begin{array}{c}\text { Resistivity } \\
(\mathbf{\Omega m})\end{array}$ & \multicolumn{1}{|c|}{ Soil Layer } & $\begin{array}{c}\text { Color } \\
\text { Configuration }\end{array}$ \\
\hline $\mathbf{0 - 1 . 6}$ & 300 & $\begin{array}{l}\text { Assumption: } \\
\text { combination } \\
\text { between sand and } \\
\text { sandy rocks as } \\
\text { well as woody } \\
\text { dry litter (dry } \\
\text { organic) }\end{array}$ & Red \\
\hline $\mathbf{1 . 6 - 3 . 5}$ & 155 & $\begin{array}{l}\text { Assumption: } \\
\text { combination } \\
\text { between hard } \\
\text { shard, sand and } \\
\text { sandy rocks and } \\
\text { also porous } \\
\text { limestone }\end{array}$ & Yellow Orange \\
\hline $\mathbf{3 . 5 - 5}$ & 73.7 & $\begin{array}{l}\text { Assumption: silty } \\
\text { clay }\end{array}$ & Green \\
\hline $\mathbf{5 - 1 5 . 7}$ & 27.9 & $\begin{array}{l}\text { Clay, loam and } \\
\text { soft shard }\end{array}$ & Blue- \\
\hline $\mathbf{3 . 6 - 1 1}$ & 16.7 & Preatic layer & Purple \\
\hline
\end{tabular}

Figure 3 indicates a curve for TM4 under replanting. There were four colors compositions indicating that there were five different color zones at each sounding measurement point at TM4 site (Table 4). The top layer was dominated with red color and the resistivity was $799 \Omega \mathrm{m}$ indicating clay and woody litter (dry organic as under replanting residue) located at a depth of $0-1.36 \mathrm{~m}$ below the surface. That soil layer was easily dry as the oil palm canopy of TM4 hasn't optimally coverred the soil from hot weather. The next layer was hard shale, sand and sandy rock, and porous limestone at $3.6 \mathrm{~m}$ to $7.5 \mathrm{~m}$ depth. The third layer was water saturated sandy clay at $5.7 \mathrm{~m}$ to $11 . \mathrm{m}$ depth. The last layer was sandy clay layer which detected at $11 \mathrm{~m}$ to $15.7 \mathrm{~m}$ depth, this layer had enough water. Sand and sandy rocks layer only occurred at $3.54 \mathrm{~m}$ to $11 \mathrm{~m}$ depth and there was a mixed layer between loam and sand or silty loam which could also be thought as a groundwater carrier layer of shallow aquifer or preatic zone.

In more detail, it can be seen that the curve shows some surface layer (0-0.05 m depth) with green and blue color 
Proc. of the Eighth International Conference On Advances in Applied Science and Environmental Engineering - ASEE 2018 Copyright (C) Institute of Research Engineers and Doctors. All rights reserved.

ISBN: 978-1-63248-143-6 doi: 10.15224/ 978-1-63248-143-6-04

distribution. This indicates root activity of the oil palm in storing water surface.

TABLE 2. SOIL TEXTURE ANALYSIS RESULT

\begin{tabular}{|c|c|c|c|c|c|c|}
\hline \multirow[t]{3}{*}{$\begin{array}{l}\text { Plant Location } \\
\end{array}$} & \multirow{3}{*}{$\begin{array}{l}\text { Depth Layer } \\
\quad(\mathrm{cm})\end{array}$} & \multicolumn{4}{|c|}{ Texture } & \multirow[t]{3}{*}{ USDA } \\
\hline & & Crude Sand & Fine Sand & Dust & Clay & \\
\hline & & \multicolumn{4}{|c|}{$\%$} & \\
\hline \multirow{3}{*}{$\begin{array}{l}\text { TM } 2 \\
\text { 3 36'45.84"SL } \\
102 \text { 17'24.08”EL }\end{array}$} & $0-20$ & 8 & 3 & 49 & 40 & sandy clay \\
\hline & $20-40$ & 4 & 2 & 20 & 74 & clay \\
\hline & $40-60$ & 3 & 1 & 20 & 76 & clay \\
\hline \multirow{3}{*}{$\begin{array}{l}\text { TM 4 } \\
3 \text { 36'53.30" SL } \\
10217 \text { '24.57” EL }\end{array}$} & $0-20$ & 6 & 3 & 36 & 55 & clay \\
\hline & $20-40$ & 6 & 3 & 31 & 60 & clay \\
\hline & $40-60$ & 8 & 3 & 35 & 54 & clay \\
\hline \multirow{3}{*}{$\begin{array}{l}\text { TM } 7 \\
\text { 3 37'24.48” SL } \\
102 \text { 14'33.69” EL }\end{array}$} & $0-20$ & 3 & 2 & 57 & 38 & sandy clay \\
\hline & $20-40$ & 3 & 2 & 42 & 53 & sandy clay \\
\hline & $40-60$ & 2 & 1 & 40 & 57 & clay \\
\hline \multirow{3}{*}{$\begin{array}{l}\text { TM 14 } \\
\text { 3 37'3.26” SL } \\
102 \text { 16'16.35” EL }\end{array}$} & $0-20$ & 8 & 4 & 49 & 39 & sandy clay \\
\hline & $20-40$ & 14 & 7 & 38 & 41 & clay \\
\hline & $40-60$ & 12 & 6 & 30 & 52 & clay \\
\hline \multirow{3}{*}{$\begin{array}{l}\text { TM } 22 \\
338 \text { '3.28” SL } \\
102152^{\prime} 10.96 ”, E L\end{array}$} & $0-20$ & 4 & 8 & 22 & 66 & clay \\
\hline & $20-40$ & 1 & 2 & 28 & 69 & clay \\
\hline & $40-60$ & 1 & 1 & 29 & 69 & clay \\
\hline \multirow{3}{*}{$\begin{array}{l}\text { Oil palm plantation - soccer field: } \\
3^{3} 38^{\prime} 21.38^{\prime} \text { SL } 102 \text { 15'51.87" EL }\end{array}$} & $0-20$ & 5 & 7 & 23 & 65 & clay \\
\hline & $20-40$ & 2 & 4 & 25 & 71 & clay \\
\hline & $40-60$ & 2 & 2 & 25 & 71 & clay \\
\hline \multirow{3}{*}{$\begin{array}{l}\text { Oil palm - residential: } 3366^{\prime} 53.58 ” \text { 'SL } \\
102 \text { 17'18.77” EL }\end{array}$} & $0-20$ & 7 & 3 & 33 & 57 & clay \\
\hline & $20-40$ & 7 & 3 & 35 & 55 & clay \\
\hline & $40-60$ & 8 & 3 & 35 & 54 & clay \\
\hline \multirow{3}{*}{$\begin{array}{l}\text { Oil palm plantation - secondary } \\
\text { forest: } 336^{\prime} 23.93 \text { 'SL } 102^{\circ} 15{ }^{\prime} 33.15^{\prime} \\
\text { EL }\end{array}$} & $0-20$ & 7 & 6 & 27 & 60 & clay \\
\hline & $20-40$ & 12 & 4 & 28 & 58 & clay \\
\hline & $40-60$ & 12 & 4 & 38 & 56 & clay \\
\hline
\end{tabular}
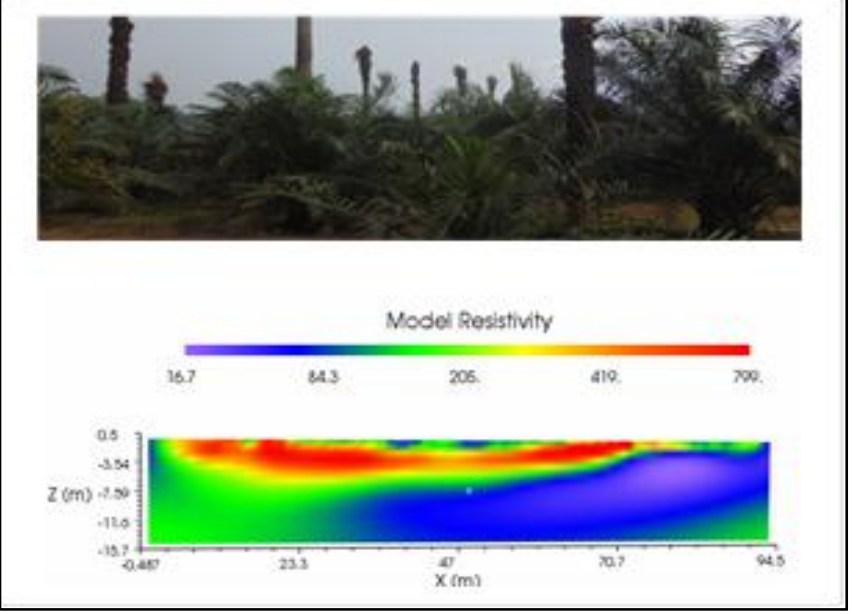

Figure 3. Geoelectrical measurement result of TM4 site

TABLE 4. GEOELECTRICAL RESULT OF TM4 (33'53.30’SL AND 102 17'24.57’EL)

\begin{tabular}{|l|l|l|l|}
\hline Depth(m) & $\begin{array}{c}\text { Resistivity } \\
(\mathbf{\Omega m})\end{array}$ & \multicolumn{1}{|c|}{ Soil layer } & \multicolumn{1}{c|}{$\begin{array}{c}\text { Color } \\
\text { configuration }\end{array}$} \\
\hline $0-3.6$ & 799 & $\begin{array}{l}\text { Assumption clay } \\
\text { soil }\end{array}$ & Red \\
\hline $3.6-5.7$ & 419 & $\begin{array}{l}\text { Assumption: mixed } \\
\text { between hard shard, } \\
\text { sand and sandy } \\
\text { rocks as well as } \\
\text { porous limestone. }\end{array}$ & Yellow-orange \\
\hline $5.7-11$ & 206 & $\begin{array}{l}\text { Assumption: sand } \\
\text { or water saturated } \\
\text { gravel }\end{array}$ & Green \\
\hline $11.0-15.7$ & 84.3 & Silty clay & Blue- \\
\hline $3.6-11$ & 16.7 & Preatic layer & Purple \\
\hline & & \multicolumn{2}{|l}{} \\
\hline
\end{tabular}

Analysis result of vertical electric sounding of TM7 is shown in Figure 4. The curve shows water surface height level corresponds to the oil palm tree location. Figure 4 shows no red color, where it equals to $1.24103 \mathrm{ohm}-\mathrm{m}$ indicating dry zone. Even at the depth over $3 \mathrm{~m}$ from the surface area, violet color was found with a high thickness $\pm 9 \mathrm{~m}$. The color in Table 5, indicates preatic groundwater which means that the root system makes a channel role as nature biopori which can absorb and store water runoff become groundwater. This can increase soil fertility by maintaining soil humidity needed by nutrients and avoid the erosion of the soil surface due to water runoff.

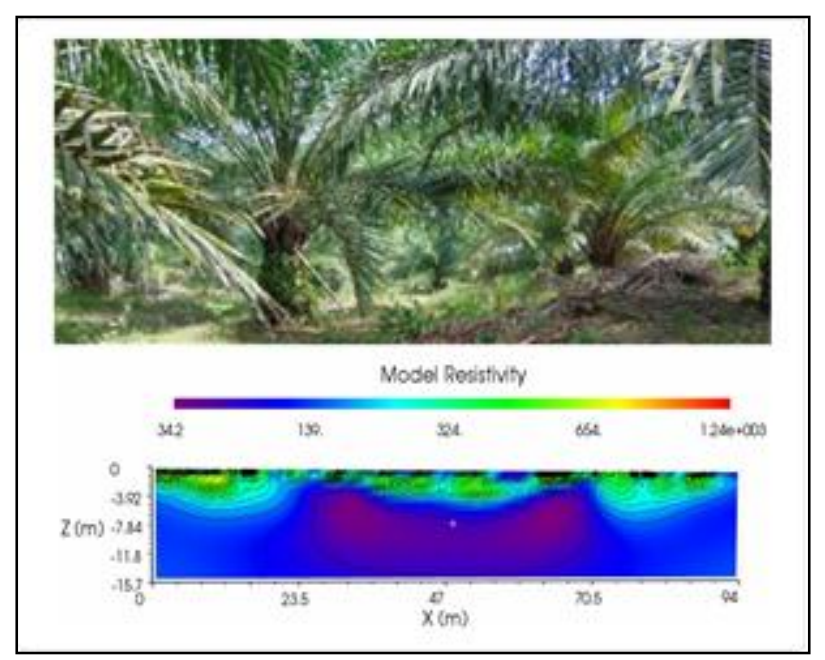

Figure 4. Geoletrical measurenment of TM7 site 
TABLE 5. GEOELECTRICAL RESULT OF TM7 (337’24.48’SL

AND $\left.102^{\circ} 14 ’ 33.69^{\prime \prime} \mathrm{EL}\right)$

\begin{tabular}{|l|l|l|l|}
\hline Depth (m) & $\begin{array}{c}\text { Resistivity } \\
(\mathbf{\Omega m})\end{array}$ & \multicolumn{1}{|c|}{ Soil Layer } & $\begin{array}{c}\text { Color } \\
\text { Configuration }\end{array}$ \\
\hline $0-3.9$ & 324 & $\begin{array}{l}\text { Predicted: sand or } \\
\text { water saturated } \\
\text { gravel and wet } \\
\text { organic manure }\end{array}$ & Green \\
\hline $3.9-15.7$ & 139 & Silty clay & Blue- \\
\hline $7.8-15.7$ & 34.4 & Preatic layer & Purple \\
\hline
\end{tabular}

Figure 5 is analysis result of TM14 site. TM14 is the most productive crops age and oftenly used as reference of water wasteful usage by oil palm tree. Based on the sounding curve in Table 6 , dry zone appears on the surface area at 0-2 $\mathrm{m}$ zone (red and yellow color). This indicates that the use of water by mature oil palm group only actives in the surface zone of the soil, whereas in the depth zone $>2 \mathrm{~m}$ the soil tend to be damp (blue color) and even indicates a shallow aquifer (purple in zone 3,92 $\mathrm{m}-15,7 \mathrm{~m}$ ) . Based on the depth, aquifer is divided into two, namely, a shallow aquifer with a depth of less than $50 \mathrm{~m}$ below the soil surface and deep aquifer at a depth of more than $50 \mathrm{~m}$ (Todd and Mays, 2005).

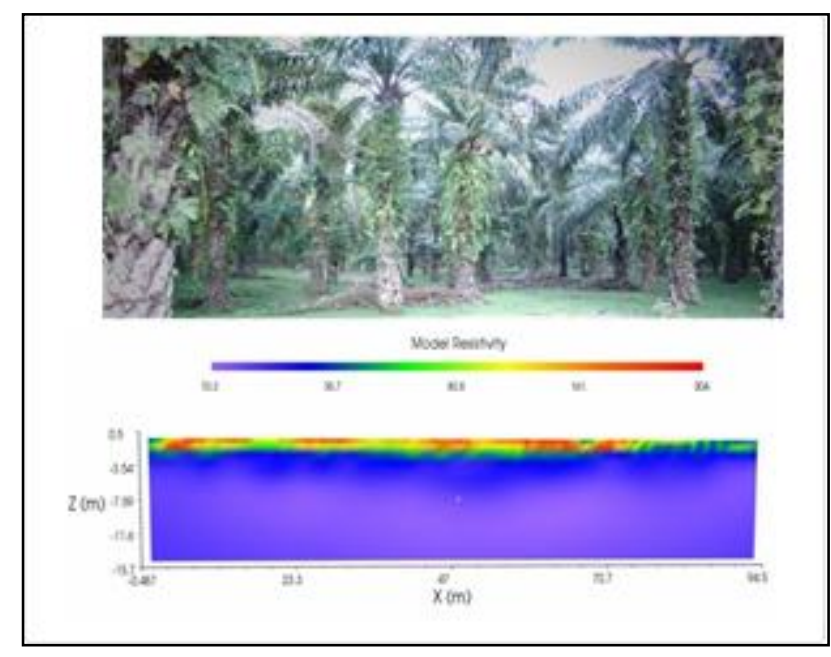

Figure 5. Geoelectrical measurement result of TM14 site

TABLE 6. GEOELECTRICAL RESULT OF TM14 ( $3^{\circ} 37^{\prime} 3.26^{\prime \prime S L}$ AND 102 16'16.35'EL)

\begin{tabular}{|l|l|l|l|}
\hline Depth(m) & $\begin{array}{c}\text { Resistivity } \\
(\mathbf{\Omega m})\end{array}$ & \multicolumn{1}{|c|}{ Soil Layer } & $\begin{array}{c}\text { Color } \\
\text { configuration }\end{array}$ \\
\hline $0-2$ & 304 & $\begin{array}{l}\text { Assumption: clay } \\
\text { soil }\end{array}$ & Red \\
\hline $0-2$ & 161 & $\begin{array}{l}\text { Assumption: } \\
\text { mixed of hard } \\
\text { shard, sand and } \\
\text { sandy rocks and } \\
\text { porous limestone }\end{array}$ & Yellow Orange \\
\hline $0-2$ & 80.8 & $\begin{array}{l}\text { Assumption: sand } \\
\text { or water saturated } \\
\text { gravel }\end{array}$ & Green \\
\hline $2-3.54$ & 36.7 & Silty clay & Blue- \\
\hline $3.54-15.7$ & 10.3 & Preatic layer & Purple \\
\hline
\end{tabular}

The next stage was measurement result at TM22 site i.e. a group of oil palm tree which will be replanted
(Figure 6) at PT. Bio Nusantara. The result showed the absence of dry zone (red or yellow), all parts appear in a high soil moisture condition. At the soil surface zone, the water usage activity of TM22 tends to be stable where as root system and organic residue has been able to maintain the equilibrium of the groundwater availability. On the measurement curve, it can be seen purple color at $7.84 \mathrm{~m}$ $-15.7 \mathrm{~m}$ depth which is peratic zone or shallow aquifer (Table 7). The older of the plant, the canopy will become wider and the plant become taller. In addition, the growth space and soil under the tree will become damper thus preatic zone is detected. Shallow aquifer at the mature plants is caused by mechanism of water balance by planting distance system and root system of the productive plant.

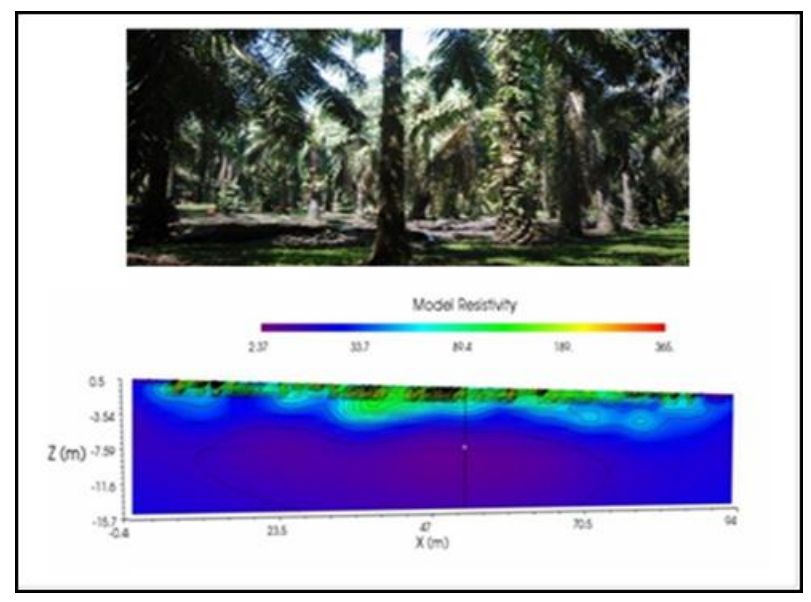

Figure 6. Geoelectrical measurement result of TM22

TABLE 7. GEOELECTRICAL RESULT OF TM 22 (33’3.28”SL AND $102^{\circ} 15^{\prime} 10.96 ”$ 'EL)

\begin{tabular}{|l|l|l|l|}
\hline Depth (m) & $\begin{array}{c}\text { Resistivity } \\
(\mathbf{\Omega m})\end{array}$ & \multicolumn{1}{|c|}{ Soil Layer } & $\begin{array}{c}\text { Color } \\
\text { configuration }\end{array}$ \\
\hline $0-3.54$ & 89.4 & $\begin{array}{l}\text { Assumption: sand or } \\
\text { water saturated gravel } \\
\text { and wet organic litter }\end{array}$ & Green \\
\hline $3.54-15.7$ & 33.7 & Silty clay & Blue- \\
\hline $7.59-15.7$ & 2.37 & Preatic layer & Purple \\
\hline
\end{tabular}

Furthermore, as a comparison, there has been measurement of vertical electric sounding at certain locations in PT Bio Nusantara i.e. between oil palm plantations with soccer field, between oil palm plantations with residential, and at the location between oil palm plantations with secondary forest. The result of the measurement analysis on the oil palm plantationsoccer field in PT Bio Nusantara showed quite stable value where the distribution of water scarcity only occurred on the surface layer while at the subsequent depth was quite aqueous / damp where the aquifer zone tend to be too shallow (Figure 7 and Table 8). It was presumably due to the near measurement location (about $400 \mathrm{~m}$ ) with the Lemau river (Lemau watershed). On the measurement curve it also indicated the same thing that oil palm plant can maintain the balance of crop water usage and surrounding environment, so that the surrounding grassland is still able to keep the soil moisture condition (Figure 7). 
Proc. of the Eighth International Conference On Advances in Applied Science and Environmental Engineering - ASEE 2018 Copyright (C) Institute of Research Engineers and Doctors. All rights reserved. ISBN: 978-1-63248-143-6 doi: 10.15224/ 978-1-63248-143-6-04

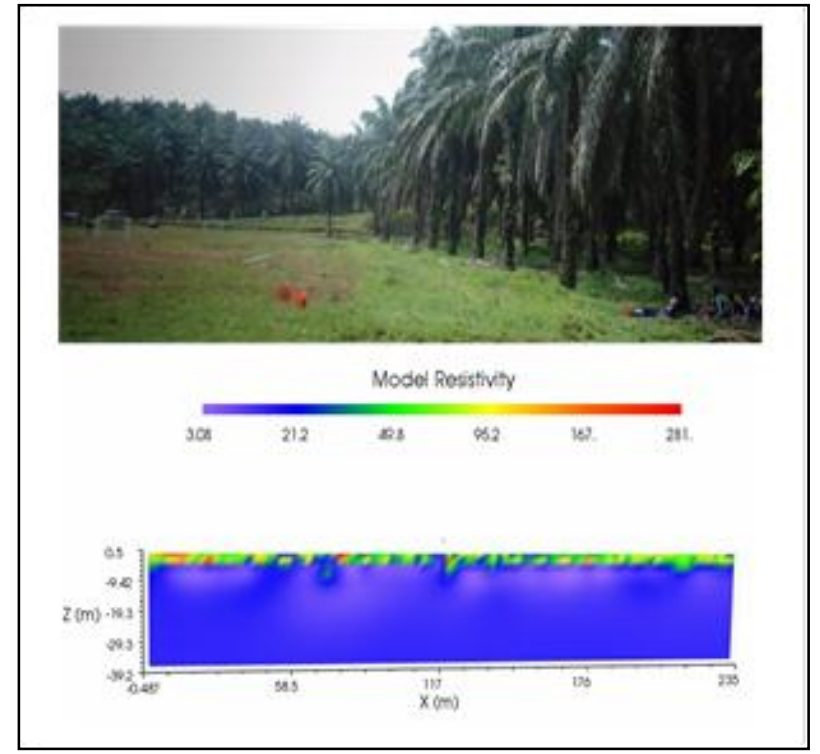

Figure 7. Geoelectric measurement result in oil palm field and soccer field

TABLE 8. GEOELECTRICAL RESULT OF OIL PALM AND SOCCER FIELD

$\left(3^{\circ} 38^{\prime} 21.38^{\prime \prime S L}\right.$ AND $\left.102^{\circ} 15^{\prime} 51.87^{\prime \prime} \mathrm{EL}\right)$

\begin{tabular}{|l|l|l|l|}
\hline $\begin{array}{c}\text { Depth } \\
(\mathbf{m})\end{array}$ & $\begin{array}{c}\text { Resistivity } \\
(\mathbf{\Omega m})\end{array}$ & \multicolumn{1}{|c|}{ Soil Layer } & \multicolumn{1}{c|}{$\begin{array}{c}\text { Color } \\
\text { Configuration }\end{array}$} \\
\hline $0-1$ & 281.0 & $\begin{array}{l}\text { Assumption: soil } \\
\text { clay }\end{array}$ & Red \\
\hline $0-4$ & 95.2 & $\begin{array}{l}\text { Assumption: } \\
\text { mixed of hard } \\
\text { shard, sand and } \\
\text { sandy rocks and } \\
\text { porous } \\
\text { limestone }\end{array}$ & Yellow Orange \\
\hline $0-4$ & 49.8 & $\begin{array}{l}\text { Assumption: } \\
\text { sand or water } \\
\text { saturated gravel }\end{array}$ & Green \\
\hline $4-39.2$ & 21.2 & silty clay & Blue- \\
\hline $5-39.3$ & 3.08 & Preatic layer & Purple \\
\hline
\end{tabular}

The next comparison was measurement on oil palm field with residential in PT Bio Nusantara (Figure 8). The result showed red and yellow color at several surface spots found in residential. However, obvious shallow aquifer zone was found at $5.88 \mathrm{~m}-11.8 \mathrm{~m}$ depth (Table 9). This shallow aquifer zone was used by resident to make wellbore for household water usage (Figure 9).

According to the testimony of the residents around PT Bio Nusantara, their bore well (Table 9) has never experienced water drought except during long dry season in every 5 or 10 years period (el nino).

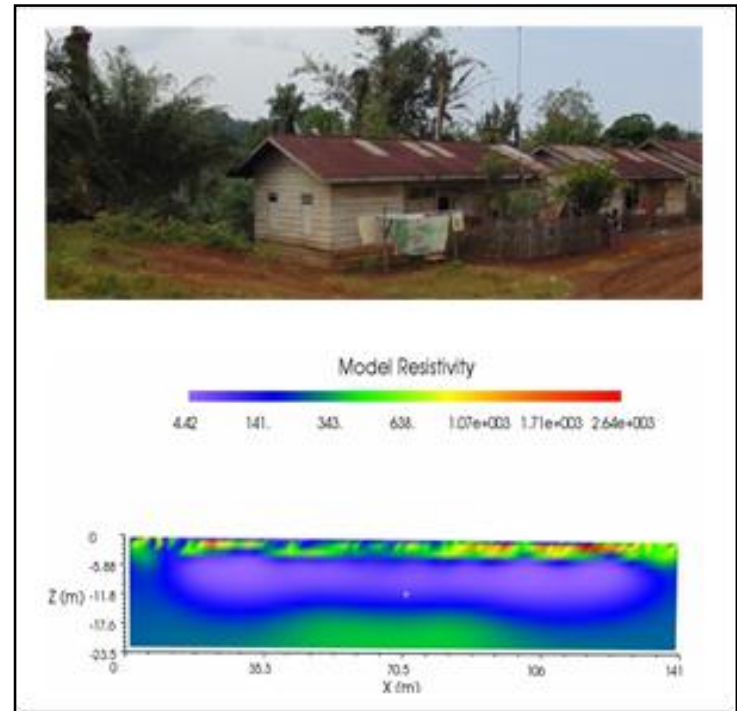

Figure 8. Geoelectrical measurement in oil palm field and residential

TABLE 9. GEOELECTRICAL RESULT OF OIL PALM PLANTATION AND RESIDENTIAL (3 36'53.58’'SL AND $\left.102^{\circ} 17^{\prime} 18.77^{\prime \prime} \mathrm{EL}\right)$

\begin{tabular}{|c|c|c|c|}
\hline $\begin{array}{c}\text { Depth } \\
\text { (m) }\end{array}$ & $\begin{array}{c}\text { Resistivity } \\
(\Omega \mathrm{m})\end{array}$ & Soil layer & $\begin{array}{c}\text { Color } \\
\text { configuration }\end{array}$ \\
\hline $0-4$ & 1007 & $\begin{array}{l}\text { Assumption: } \\
\text { mixed of hard } \\
\text { shard, sand sandy } \\
\text { rocks and porous } \\
\text { limestone }\end{array}$ & Yellow Orange \\
\hline $\begin{array}{l}0-5.88 \\
17.6- \\
23.5\end{array}$ & 638 & $\begin{array}{l}\text { Assumption: sand } \\
\text { or water saturated } \\
\text { gravel }\end{array}$ & Green \\
\hline $0-17.6$ & 141 & Silty clay & Blue- \\
\hline $\begin{array}{l}5.88- \\
11.8\end{array}$ & 4.42 & Preatic layer & Purple \\
\hline
\end{tabular}

Final measurement for comparison purpose was conducted in oil palm plantation-secondary forest in PT Bio Nusantara ring area (Figure 10). The result in Table 10 showed red and yellow color distribution indicating water scarcity, however this water scarcity was located in secondary forest location. This confirms that proper oil palm planting distance and oil palm root system are able to form a good balance of water for the surrounding environment.

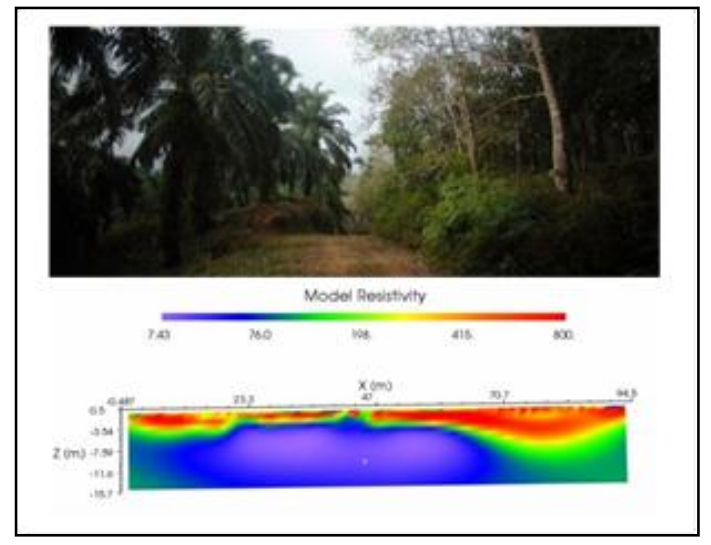

Figure 10. Geoelectrical measurement result in oil palm and secondary forest site

Measurement point of oil palm plantation - secondary forest was seen at $3.54 \mathrm{~m}$ depth where it was dominated 
with clay acting as impermeable layer (Table 10). Sand and sandy rocks layer only occurred at $4 \mathrm{~m}-12 \mathrm{~m}$ depth and there were also loam and silty or silty loam layer which presumably acted as groundwater carrier layer i.e. shallow aquifer or preatic zone.l

TABLE 10. GEOELECTRICAL RESULT OF OIL PALM SECONDARY FOREST ( $3^{\circ} 36^{\prime} 23.93$ ”SL AND 102 15’33.15”EL)

\begin{tabular}{|c|c|c|c|}
\hline $\begin{array}{c}\text { Depth } \\
\text { (m) }\end{array}$ & $\begin{array}{c}\text { Resistivity } \\
(\Omega \mathrm{m})\end{array}$ & Soil layer & $\begin{array}{c}\text { Color } \\
\text { configuration }\end{array}$ \\
\hline $0-3.54$ & 800 & $\begin{array}{l}\text { Assumption: mixed } \\
\text { of clay and wooden } \\
\text { litter dry organic) }\end{array}$ & Red \\
\hline $3-4$ & 415 & $\begin{array}{l}\text { Assumption: mixed } \\
\text { of hard shard, sand } \\
\text { and sandy rocks and } \\
\text { also porous } \\
\text { limestone }\end{array}$ & Yellow-Orange \\
\hline $4-7.59$ & 198 & $\begin{array}{l}\text { Assumption: sand or } \\
\text { water saturated } \\
\text { gravel }\end{array}$ & Green \\
\hline $\begin{array}{l}3.54- \\
15.7\end{array}$ & 76 & Silty clay & Blue- \\
\hline $4-12$ & 7.43 & Preatic layer & Purple \\
\hline
\end{tabular}

\section{Conclusion}

The type of soil found in the study site was cambisol. Cambisol is a developed soil, indicated by $\mathrm{A}-\mathrm{Bw}-\mathrm{C}$ horizon layer on well drained soil, and $\mathrm{A}-\mathrm{Bg}-\mathrm{C}$ horizon layer on inhibited drained soil. The soil texture at the study site showed that high clay content with clay texture didn't only have a large surface but also contained of electric charge. Electrical charge gives clay properties to bind water or plant nutrient on its surface. This makes clay to store more water. But clay is also an impermeable layer when it appears below ground level.

The result of vertical electric sound curve analysis on TM2 and TM4 which used to be under-replanting area showed rocks distribution, clay and dry litter (underreplanting residue) thus showing red and yellow color indicating water scarcity. At the next depth, blue color dominated and purple color indicating high groundwater especially purple color which presumably thought as shallow aquifer. At the measurement analysis in TM7, TM14 and TM22, dry zone didn't found, all parts of soil had high moisture. At the soil surface, water usage activity on oil palm TM22 was stable indicating that the root system and plant organic residue were able to maintain plant water availability balance.

As a comparison, the oil palm site which compared with soccer field showed no different vertical electric sounding curve result. This confirmed that oil palm plantation was able to maintain the balance of water usage of the plants and surrounding environment. Thus, soccer field grown with grass was able to maintain the soil moisture. At the oil palm plantation-residential, result showed red and yellow color in several surface spots in which generally found in residential. However, uniquely, it was found obvious shallow aquifer at 5,88$11,8 \mathrm{~m}$ depth which then used by residents to make wellborr for their household water needs. At oil palm plantation-secondary forest, the result showed red and yelllow color indicating water scarcity, but this condition occurred at secondary forest site. This further confirmed that proper planting distance and root system of oil palm was able to maintain good water balance for surounding area.

The older of the oil palm tree makes canopy getting wider and the height getting taller. In addition, the growing space and the soil consition below the tree gets damper thus reatic zone is detected or shallow aquifer under the oil palm tree produces mature age which presumably caused by water balance mechanism between planting distance system and root system of the mature tree on that site.

\section{References}

[1] Abidin, M H Z; Saad, R; Ahmad, F; Wijeyesekera, D C and Yahya, A, "Soil moisture content and density prediction using laboratory resistivity experiment," IACSIT International Journal of Engineering and Technology, vol. 5(6), pp. 731-735, 2013.

[2] Bhatt, S and Jain, P K, "Correlation between electrical resistivity and water content of sand - a statistical approach," American International Journal of Research in Science, Technology, Engineering \& Mathematics, vol. 6(2), pp. 115-121. 2014.

[3] BBSDLP, Peta Semi Detail Bengkulu Tengah Skala 1: 50.000, 2016.

[4] Dong, C; Schoups, G and Giesen, N V D, "Scenario development for water resource planning and management,", A review. Technological Forecasting and Social Change, vol. 80(4), pp. 749761, 2013

[5] Elfadaly, H A; Hassanain, N A; Hassanain, M A; Barakat, A M and Shaapan, R M, "Evaluation of primitive ground water supplies as a risk factor for the development of major waterborne zoonosis in Egyptian children living in rural areas," Journal of Infection and Public Health, Article In Press, 2017.

[6] Kovacic, A; Huljev, Z and Susic, E, "Ground water as the source of an outbreak of Salmonella Enteritidis," Journal of Epidemiology and Global Health, vol. 7, pp. 181-184, 2017.

[7] Mays, L W, "Water Resources Enginnering," Second edition. America (US): John Wiley \& Sons, 2006.

[8] Mohamaden, M I I, "Assessment of the wastewater effect on the shallow subsurface soil at Farafra Oasis, Egypt, by using geoelectrical and geochemical data analysis," NRIAG Journal of Astronomy and Geophysics, vol. 5, pp. 306-312, 2016.

[9] Mostafa, M; Anwar, M B and Radwan, "A Application of electrical resistivity measurement as quality control test for calcareous soil," Housing and Building National Research Center Journal, Article In Press, 2017.

[10] Muchingami, I; Hlatywayo, D J; Nel, J M; Chuma, C, "Electrical resistivity survey for groundwater investigations and shallow subsurface evaluation of the basaltic-greenstone formation of the urban Bulawayo aquifer," Journal of Physics and Chemistry of the Earth, pp. 50-52, 2012.

[11] Oni, T E; Omosuyi, G O and Akinlalu, A A, "Groundwater vulnerability assessment using hydrogeologic and geoelectric layer susceptibility indexing at Igbara Oke, Southwestern Nigeria," NRIAG Journal of Astronomy and Geophysics, vol. 6, pp. 452-458, 2017.

[12] Orlando, L, "Some considerations on electrical resistivity imaging for characterization of waterbed sediments," Journal of Applied Geophysics, vol. 95, pp. 77-89, 2013.

[13] Puslitbang Geologi, "Peta geologi bersistem Indonesia; lembar Bengkulu (0912) Sumatera Skala 1:250.000," Pusat Penelitian dan Pengembangan Geologi, Bandung, 1992.

[14] Salem, W M and El-Sayed, M, "Hydro-geochemical and isotopic composition of ground water in Helwan area," Egyptian Journal of Petroleum, vol. 24, pp. 411-421, 2015.

[15] Sheriff, Re, "Encyclopedic Dictionary of Applied Geophysics" 4th Edition,Oklahoma (US), SEG Tulsa, 2002.

[16] Smith, W B; Miller, G R and Sheng, Z, "Assessing aquifer storage and recovery feasibility in the Gulf Coastal Plains of Texas," Journal of Hydrology: Regional Studies, vol. 14, pp. 92-108, 2017. 
[17] Soeharto, B B, "Faktor-faktor yang mempengaruhi simpanan air tanah : Studi kasus kota Jakarta dan sekitarnya," Program Studi Ilmu Lingkungan. Program Pasca Sarjana Universitas Indonesia, Jakarta, 1997.

[18] Soil Survey Staff, "Keys to Soil Taxonomy. 12nd ed," USDA Natural Resources Conservation Service, Washington DC, 2014.

[19] Subardja, D S; Ritung, S; Anda, M; Sukarman; Suryani, E and Subandiono, R E, "Petunjuk teknis klasifikasi tanah," Revision Ed, BBSDLP, Bogor, 2016.

[20] Subramaniam, S; Muhamad, H; Hashim, Z and May, C Y, "Water footprint: Part 3- The production of crude palm oil in Malaysian palm oil mills," Journal of Oil Palm Research, vol. 26(4), pp. 292-299, 2014.

[21] Todd, D K and Mays L W, "Groundwater hydrology," 3th ed. Denver (US): John Wiley \& Sons, Inc, 2005.

[22] Wahyudi, F R and Moersidik, S S, "The analysis of ground water availability and utility in DKI Jakarta," Procedia-Social and Behavioral Sciences, vol. 227, pp. 799-807, 2016.

\begin{tabular}{|l|l|}
\hline & $\begin{array}{l}\text { Riska Ekawita received the BSc degree in physics } \\
\text { department from Andalas University in } 2004 \text { and } \\
\text { MSc and PhD degree in physics electronics from } \\
\text { Institut Teknologi Bandung (ITB), Indonesia in 2009 } \\
\text { and 2015, respectively. She is currently an assistant } \\
\text { professor in Department of Physics, Mathematic and } \\
\text { Natural Science Faculty, Bengkulu University. She is } \\
\text { involved in research on electronic and } \\
\text { instrumentation of physics. }\end{array}$
\end{tabular}

\begin{tabular}{|l|l|} 
Zul Bahrum Caniago was born in Padang, \\
November 25, 1957. He obtained BSc degree in \\
Physics Education at State University of Yogyakarta \\
(UNY) in 1984. His MSc degree in Physics \\
Instrumentation was achieved at Institut Teknologi \\
Bandung (ITB) in 1991. He got his PhD degree in \\
Environment Science from Sriwijaya University in \\
2014. He is currently interested in the development
\end{tabular}

\begin{tabular}{|l|l|}
\hline & $\begin{array}{l}\text { Supanjani passed his BSc degree in agronomy at } \\
\text { Bogor Agriculture University in 1986. His MSc } \\
\text { degree in Plant Science was achieved at Massey } \\
\text { University, New Zealand in 1991. He got his PhD } \\
\text { degree in Plant Science from McGill University, } \\
\text { Canada. He is currently interested in the } \\
\text { development of cultivation technologies of guava } \\
\text { and date palm, and the ecology of oil palm. }\end{array}$ \\
\hline
\end{tabular}

\begin{tabular}{|l|l|} 
& $\begin{array}{l}\text { Abimanyu Dipo Nusantara got his BSc in soil } \\
\text { science from Jember University in 1981, MSc degree } \\
\text { in soil science from Gajah Mada University in 1986 } \\
\text { and PhD in forest science from Bogor Agriculture } \\
\text { University in 2011. He is currently interested in the } \\
\text { development of soil microorganism consortium for } \\
\text { remedying problem of soil. }\end{array}$ \\
\hline
\end{tabular}

Yazid Ismi Intara received the BSc degree in
agronomy department from Mulawarman University
in 1999 and MSc and PhD degree in agriculture
engineering from Bogor Agriculture University,
Indonesia in 2005 and 2012, respectively. He is
currently an assistant professor in Faculty of
Agriculture in Mulawarman University. He is
currently interested in the agriculture and irrigation
engineering.

